\title{
Utility of Real-Time PCR in the Diagnosis of Primary Epstein-Barr Virus Infection
}

Constantina Gartzonika1, Georgia Vrioni², Efthalia Priavali ${ }^{1}$, Georgios Pappas ${ }^{3}$ and Stamatina Levidiotou ${ }^{1 *}$

${ }^{1}$ Department of Microbiology, Medical School, University of loannina, loannina, Greece

${ }^{2}$ Department of Microbiology, Medical School, University of Athens, Athens, Greece

3 Institute of Continuing Medical Education of loannina, Ioannina, Greece

\begin{abstract}
Background: Despite the availability of several serological markers, Epstein-Barr virus (EBV) status of some patients is not easily resolved.

Objectives: The aim of the present study was to investigate the quantification and the diagnostic utility of EBV DNA detection as an adjunct to serological diagnosis of primary EBV infection.

Study Design: Sera from 118 patients referred for suspected primary EBV infection, were tested for heterophile antibodies (HA), IgM antibodies against viral capsid antigen (VCA IgM) and IgG against nuclear antigen (EBNA IgG). A quantitative real time EBV PCR assay (Light Cycler EBV Quant kit) was simultaneously performed in plasma of these patients.

Results: EBV DNA was detected in 43 of 46 patients (93.5\%) with serologically confirmed primary infection. By performing real time RCR in the remaining 72 samples, 24 additional cases were diagnosed: in 20 of them, VCA IgM was positive but not $\mathrm{HA}$; in 4 cases, HA were positive, but not VCA IgM. EBV DNA load was detectable in all samples drawn until day 12 after onset of symptoms; 20 days after onset all samples were negative. Higher viral load levels were detected in younger patients and in male patients

Conclusions: The use of EBV PCR assay resulted in an increase in definitive diagnosis of primary EBV infection, enhancing overall diagnostic efficacy by $20.3 \%$. Real time PCR is a reliable tool for diagnosis of primary EBV infection early in the course of disease and may especially serve as a useful diagnostic supplement in serologically unclear cases of EBV infection.
\end{abstract}

Keywords: EBV; Infectious mononucleosis; Diagnosis; Real-time quantitative PCR; Serology

Abbreviations: EBV: Epstein-Barr Virus; HA: Heterophile Antibodies; VCA IgM: IgM antibodies against Viral Capsid Antigen; EBNA IgG: IgG against Nuclear Antigen; IM: Infectious Mononucleosis; PCR: Polymerase Chain Reaction

\section{Introduction}

The vast majority of the world adult population exhibits serologically past contact with Epstein-Barr virus (EBV). Acute infection is usually subclinical in early childhood and presents as Infectious Mononucleosis (IM) in $30-50 \%$ of cases involving adolescents and young adults $[1,2]$. Moreover, a variety of human malignancies have been etiologically linked to EBV infection $[3,4]$.

Serology remains the gold standard for diagnosis of primary EBV infection in immunocompetent patients. IM diagnostics in particular typically involve a combination of serological markers as heterophile antibodies (HA), IgM antibodies against Viral Capsid Antigen (VCA IgM), VCA IgG and IgG against Nuclear Antigen (EBNA IgG) [5]. Nonetheless, despite the availability of several different serological markers, serology is not always able to accurately determine the stage of infection since false positive and false negative results are regularly observed [6]. A positive HA test has a sensitivity and a specificity of approximately $85 \%$ and $97 \%$ respectively for the diagnosis of IM [7] but these tests are negative in $25 \%$ of patients during the first week of infection and positive in only $25-50 \%$ of children under 12 years of age $[7,8]$. VCA IgM tests are useful in diagnosing patients with clinical suspicion of primary EBV infection but false negative results may occur due to the transient nature of the VCA-IgM response. Conversely, false positive IgM reactions occur due to autoantibodies or other serum factors and due to cross-reactions to other recent infections $[6,9]$. There is thus a continuous quest for novel diagnostic methods that can enhance accuracy, including molecular assays as EBV Polymerase Chain Reaction (PCR). It has been suggested that quantitative Viral Load (VL) assessment is superior to qualitative detection since, applying assays commonly used in the clinical laboratory, EBV DNA can sometimes be detected in immunocompetent individuals and often in immunosuppressed patients without symptoms or clinical sequelae [10]. Real-time PCR is a more rapid, sensitive, specific and reproducible method for detecting and monitoring the levels of EBV in comparison to conventional PCR [11].

\section{Objectives}

The aim of the present study was mainly to investigate the diagnostic utility of quantitative EBV DNA detection in support of serological diagnosis of acute EBV infections, to evaluate the significance of EBV DNA plasma levels kinetics, and their correlation with clinical disease.

*Corresponding author: Stamatina Levidiotou, Department of Microbiology, Medical School, University of Ioannina, 45110 Ioannina, Greece, Tel: +30 2651007589; Fax: +30 2651007885, E-mail: sleveidi@uoi.gr

Received October 30, 2012; Accepted December 17, 2012; Published December 28, 2012

Citation: Gartzonika C, Vrioni G, Priavali E, Pappas G, Levidiotou S (2012) Utility of Real-Time PCR in the Diagnosis of Primary Epstein-Barr Virus Infection. J Med Microb Diagn 1:118. doi:10.4172/2161-0703.1000118

Copyright: (C) 2012 Gartzonika C, et al. This is an open-access article distributed under the terms of the Creative Commons Attribution License, which permits unrestricted use, distribution, and reproduction in any medium, provided the original author and source are credited. 


\section{Materials and Methods}

\section{Patients and controls}

Clinical samples from 118 patients with a clinical suspicion of IM/ acute EBV infection, aged 1 to 47 years (median 21 years), 58 males and 60 females were included in the study. Demographic and clinical information was obtained by medical records review. Transplant recipients and patients who had a previous acute illness that was consistent with IM were excluded. The patient cohort consisted of 20 (17\%) children (aged 1-10 years, median 4 years), 19 (16\%) adolescents (aged 11-18 years median; 16 years) and 79 (67\%) adults (aged 19-47, median 32 years). Thirty-eight (32.2\%) of the patients were hospitalized (median 6.3 days) because of the severity of their infection. One hundred and nine (92.4\%) were immunocompetent while the underlying main diseases in the immunocompromised patients were hematological malignancies $(n=7)$ and HIV/AIDS $(n=2)$. Four patients had T-cell lymphoma and the remaining three non-Hodgkin lymphoma. The time interval between onset of disease and first sampling was 2 to 15 days (median 4.5 days). EBV serologic tests and quantification of EBV DNA were performed in serum and plasma respectively. In addition eighteen EBV DNA positive immunocompetent patients were retested at either day twelve, fifteen, or twenty thereafter. Eight of these patients were sampled twice during follow-up, while three samples were collected from one patient.

Twenty EBV seronegative patients and fifteen healthy EBV carriers (determined by the presence of EBNA IgG and the absence of VCA $\operatorname{IgM}$ ) acted as control individuals in the study (19 men and 16 women, age range, $15-38$ years; median 29 years).

\section{EBV serologic assays}

Single serum samples from enrolled patients were tested simultaneously for VCA IgM, EBNA-1 IgG and HA. IgM and IgG antibodies to EBV VCA and EBNA-1 respectively were measured using commercially available enzyme-linked immunosorbent assays kits (ELISA: Virion/Serion GmbH, Germany) while HA was determined by use of the Cellognost-Mononucleosis test (Siemens Health care Diagnostics, GmbH, Germany). In addition in EBV DNA positive patients, VCA IgG avidity was performed to rule out an apparent reactivation. All assays were performed according to the manufacturer's instructions.

\section{Quantitative PCR}

A quantitative real time EBV PCR assay in plasma samples (Light Cycler EBV Quant kit, Roche Diagnostics GmbH, Mannheim, Germany) was performed in all patients with negative EBNA-IgG. Viral DNA was extracted from $200 \mu \mathrm{l}$ of plasma samples according to the instructions of a special appendix for High Pure Viral Nucleic Acid Kit (Roche Diagnostics) included in the Light Cycler ${ }^{\circledR}$ EBV Quant Kit. An Internal Control (IC) was introduced into the clinical samples during preparation and a Non-Template Control (NTC) was prepared in parallel with the clinical samples. Four calibrators (Light Cycler ${ }^{\circledR}$ EBV Cal 1-4) were used both to enable the quantitation of EBV and to check the validity of each run. The RCR reaction was carried out in a final volume of $20 \mu \mathrm{l}$ per capillary using $10 \mu \mathrm{l}$ of working mastermix contained Light Cycler EBV ${ }^{\circledR}$ MMx plus Light Cycler Mg 20 and 10 $\mu \mathrm{l}$ of extracted DNA (clinical sample DNA or NTC DNA) or EBV Cal 1-4. All samples were run in a LightCycler ${ }^{\circledR} 2.0$ Instrument (Roche Diagnostics). The Light Cycler EBV quantification kit uses a specific pair of FRET hybridization probes to detect a fragment of the latent membrane protein [12]. The Limit of Detection (LOD) was determined to 229 copies $/ \mathrm{ml}$, as specified in the user manual.

\section{Interpretation}

Patients were diagnosed with primary EBV infection if they had a consistent clinical syndrome (two or more of the following: lymphathenopathy, pharyngitis, fever, rash or fatigue) and were found to be negative for EBNA IgG and positive either for 1) VCA IgM and HA or 2) EBV DNA and one of the serological assays (VCA IgM/HA).

\section{Statistical analysis}

Statistical analyses were performed with Statistica software package (version 7.0). The EBV DNA loads were associated with clinical (days after onset of symptoms) and demographic data using the Spearman rank correlation analysis and the Wilcoxon rank sum test. Statistical significance was taken as $\mathrm{p}<0.05$.

\section{Results}

EBV DNA was detected in 67 of 118 enrolled patients with a median viral load of $5.02 \times 10^{3}$ copies $/ \mathrm{ml}$ (range $2.85 \times 10^{2}-7.6 \times 10^{4}$ copies $/ \mathrm{ml}$ ). Plasma samples obtained from the 35 control individuals were all EBV DNA negative. None of the purified DNA samples inhibited the amplification of the internal control. Forty-six patients were diagnosed with acute EBV infection based on the presence of VCA IgM and HA; of these, 43 (93.5\%) were EBV DNA positive and the measured viral loads ranged from $4.56 \times 10^{2}$ to $7.6 \times 10^{4}$ copies $/ \mathrm{ml}$. The three patients with a seroprofile matching a primary EBV infection and a negative PCR assay were sampled 13 to 15 days after symptom-onset. If a positive EBV PCR result with either positive VCA IgM or positive HA was considered as proof of EBV infection, then, by performing real time RCR in the remaining 72 samples, we were able to detect the presence of a primary infection in twenty four extra cases (Table 1). Sixty percent of the IgM positive and HA negative group with IM (12/20) were children (median 4.5 years). Five percent of the same group (1/20) and $25 \%$ of the IgM negative and HA positive group (1/4) were immunosuppressed with hematological malignancies. According to the criteria listed above for determining primary EBV infection the sensitivity, specificity, positive and negative predictive values for the quantitative real time EBV PCR assay were $95.7 \%, 100 \%, 100 \%$ and $94.4 \%$, respectively. In EBV DNA positive patients, primary EBV infection was confirmed by the presence of low avidity antibodies and in all patients with IM (70/118) the clinical data and laboratory findings were consistent with the diagnosis (Table 2).

There was a significant association found between EBV DNA load and time after disease onset, with plasma EBV DNA levels decreasing during the evolution of IM (Figure 1). We furthermore observed a higher median viral load in the group of children and adolescents

\begin{tabular}{|l|c|c|c|}
\hline & Patients & $\begin{array}{c}\text { Diagnosis based on } \\
\text { seroprofilea and } \\
\text { real-time PCR }\end{array}$ & $\begin{array}{c}\text { Real-time PCR } \\
\text { No of patients positive/ } \\
\text { no.tested (median load) }\end{array}$ \\
\hline $\begin{array}{l}\text { VCA IgM (+), HA(+), } \\
\text { EBNA IgG (-) }\end{array}$ & 46 & $\begin{array}{c}\text { IM (46) } \\
\text { No EBV infection (0) }\end{array}$ & $43 / 46\left(4.57 \times 10^{3}\right)$ \\
\hline $\begin{array}{l}\text { VCA IgM (+), HA (-), } \\
\text { EBNA IgG (-) }\end{array}$ & 63 & $\begin{array}{c}\text { IM (20) } \\
\text { No EBV infection (43) }\end{array}$ & $\begin{array}{c}20 / 20\left(6.1 \times 10^{3}\right) \\
0 / 43\end{array}$ \\
\hline $\begin{array}{l}\text { VCA IgM (-), HA (+), } \\
\text { EBNA IgG (-) }\end{array}$ & 9 & $\begin{array}{c}\text { IM (4) } \\
\text { No EBV infection (5) }\end{array}$ & $\begin{array}{c}4 / 4\left(4.98 \times 10^{3}\right) \\
0 / 5\end{array}$ \\
\hline $\begin{array}{l}\text { Total } \\
\text { (with variable } \\
\text { serological profile) }\end{array}$ & 118 & $\begin{array}{c}\text { IM (70) } \\
\text { No EBV infection (48) }\end{array}$ & $\begin{array}{c}67 / 70\left(5.02 \times 10^{3}\right) \\
0 / 48\end{array}$ \\
\hline
\end{tabular}

Table 1: Correlation between results of EBV serology and real-time PCR. 


\begin{tabular}{|l|c|}
\hline Characteristics & Value \\
\hline Demographics & \\
\hline Male sex; $\mathrm{n}(\%)$ & $33(47.14)$ \\
\hline Adults; $\mathrm{n}(\%)$ & $40(57.14)$ \\
\hline Hospitalized patients; $\mathrm{n}(\%)$ & $15(21.42)$ \\
\hline Immunocompetent patients; $\mathrm{n}(\%)$ & $68(97.14)$ \\
\hline Clinical characteristics (signs and symptoms) & \\
\hline Lymphadenopathy; $\mathrm{n}(\%)$ & $69(98.57)$ \\
\hline Pharyngitis; $\mathrm{n}(\%)$ & $67(95.71)$ \\
\hline Fever (>37.5 $\mathrm{C}) ; \mathrm{n}(\%)$ & $50(71.42)$ \\
\hline Fatigue; $\mathrm{n}(\%)$ & $43(61.42)$ \\
\hline Rash; $\mathrm{n}(\%)$ & $25(35.71)$ \\
\hline
\end{tabular}

Table 2: Epidemiological and clinical characteristics of 70 patients with EBV primary infection.

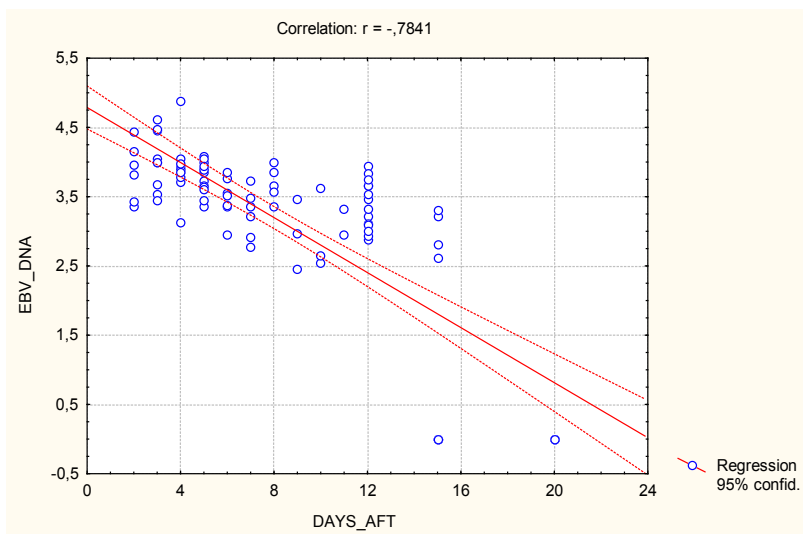

Figure 1: Association between viral load (copies/ml, log10) and the phase of infection (days after onset of disease). Day 0 represents the day of onset of symptoms. Each point represents one sample. In the follow up samples drawn day twenty of illness no EBV DNA was detectable.

\begin{tabular}{|l|c|c|c|}
\hline Parameter & Number & P-value & Correlation coefficient \\
\hline $\begin{array}{l}\text { Days after onset of } \\
\text { disease }{ }^{\mathrm{a}, \mathrm{c}}\end{array}$ & 95 & $<0.001$ & -0.42 \\
\hline Age $^{\mathrm{a}, \mathrm{d}}$ & 67 & $\mathrm{NS}$ & -0.118 \\
\hline Male gender $^{\mathrm{b}, \mathrm{e}}$ & 67 & $<0.001$ & - \\
\hline
\end{tabular}

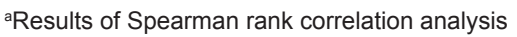

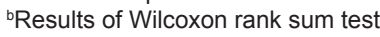

'Higher viral load early in the course of disease

${ }^{d}$ Higher viral load in younger patients but NS (No Significant)

eHigher viral load in male patients

Table 3: Correlation between viral load (copies $/ \mathrm{ml}$ ) and data in primary EBV infection.

compared to adults $\left(6.19 \times 10^{3}\right.$ copies $/ \mathrm{ml}$ versus $4.49 \times 10^{3}$ copies/ $\mathrm{ml}$ ); although not reaching statistically significant levels, this did demonstrate a possible correlation between viral load and patient age. A significant association also observed between viral load levels and male gender, not systematically reproduced in similar studies [13], and not readily explained pathophysiologically, is an issue that warrants further evaluation (Table 3).

In order to determine the variability of EBV clearance during IM evolution, a total of 28 plasma samples were collected from eighteen EBV DNA positive patients at day twelve (12/28), fifteen (11/28) and twenty (5/28) after the onset of symptoms. EBV viral load was highest at the time of first sampling in all patients and declined thereafter during the early convalescent period. EBV DNA was detectable in all samples drawn until (and including) day 12 after onset of symptoms. At day 15 after onset of primary infection, $36.4 \%$ (4/11) of patients had detectable EBV DNA and all of them showed a significant decrease in viral load between the first and the follow-up samples. All five samples obtained on day 20 were EBV DNA negative, three of these belonging to patients who were EBV DNA positive on day 15.

\section{Discussion}

There are many studies which support the utility of quantitative EBV viral load assessments in the pre-emptive management and monitoring of EBV associated disease in immunosuppressed patients, but few which investigate the quantification and the diagnostic utility of EBV DNA detection as an adjunct to serological diagnosis of primary EBV infection.

In the present study, data show that EBV DNA was detected in the plasma of patients undergoing primary infection with a sensitivity (95.7\%) and a specificity (100\%), similar to the findings by other authors [13-16] or higher than previously reported [17-20]. In contrast to our results many of these investigators analyzed samples from patients with proven and not suspected EBV infection [13,14,17-19]. Using serological markers, they were detected 46 out of 70 cases of primary EBV infection in the group of 118 patients suspected for IMlike syndrome. EBV PCR led to a $20.3 \%$ rise in the number of primary EBV infection diagnoses as compared with serology-based diagnostic approach. This increase was the result of the detection of EBV DNA in patients with acute infection who exhibited delayed VCA IgM appearance or who failed to produce detectable levels of HA. Luderer et al. [21], found a lower increase (16\%) in definitive diagnosis of primary EBV infection using EBV PCR, but these researchers only studied a group of IgM VCA positive patients. It seems that PCR may be more sensitive than serology in the first days of illness as the immunologic response to infection may not be detected for several days. VCA IgM and HA were negative in $6 \%$ and $30 \%$ of EBV PCR positive cases respectively and that means that in the case of HA tests the possibility of false negative result, mainly in children, must be taken into account, as observed previously [18]. The findings in the present study that over one third of the patients (36.4\%) with non-EBV infections (infections with Cytomegalovirus, Hepatitis A Virus, Toxoplasma or Parvovirus B19 as were diagnosed using serological or molecular assays) had demonstrable VCA IgM antibodies, underlines the frequent occurrence of false-positive IgM VCA results, raising concerns about reliance upon this assay alone for diagnosis $[9,19,21]$.

Conversely, PCR was negative in 3 of 46 cases diagnosed serologically as primary EBV infection. Absence of EBV DNA detection correlated to the phase of infection in which the samples were collected (13 to 15 days after onset of symptoms). The results show that all plasma samples drawn at day 12 exhibited detectable EBV DNA, and the first negative PCR results were observed at day 15 after disease-onset, indicating that PCR had an $100 \%$ positivity in plasma collected during the early acute phase of infection (within 12 days after the onset of disease). Follow-up assessment of EBV DNA load in plasma confirms-with few differences in the duration of PCR positivity-previous reports of a transient presence of EBV DNA during acute phase of primary infection limiting the applicability of EBV PCR early in the course of disease $[10,13$ $15,17,22]$. Additionally, other studies supported that this relatively rapid viral elimination from plasma may prove to be a good indicator of the host's control of EBV infection [11,23]. It is well established that the immune system play the main role in the elimination of EBV DNA but further investigations will be necessary to understand the possible active role of EBV-specific CD8+ T cells [24] or B cells [25]. 
Citation: Gartzonika C, Vrioni G, Priavali E, Pappas G, Levidiotou S (2012) Utility of Real-Time PCR in the Diagnosis of Primary Epstein-Barr Virus Infection. J Med Microb Diagn 2:118. doi:10.4172/2161-0703.1000118

Page 4 of 4

Measuring the EBV DNA in plasma and determining the duration of viremia in immunocompetent patients may help us to understand EBV infection in immunosuppressed hosts [23]. Unfortunately in our study the number of immunocompromised patients with primary EBV infection was too small (2/9) for definite conclusions and the literature is very limited to analyse but we believe that extended studies in such a group of patients may support our results and clearly demonstrate the role of EBV viremia in the diagnosis of IM.

In conclusion, although EBV DNA presence is short-lived after onset of symptoms, giving it a low negative predictive value, its detection in plasma has high sensitivity in primary EBV infection. An EBV PCR should be considered in cases of positive IgM VCA and negative HA because it is difficult to exclude the possibility of a false positive IgM VCA or false negative HA. Thus, in cases of inconclusive serological results, plasma EBV DNA may serve as a useful and valuable diagnostic tool in the early diagnosis of an acute primary EBV infection. Nevertheless, the clinical value of monitoring EBV DNA load in plasma during primary EBV infection remains further to be established.

\section{References}

1. Lennette ET (1995) Epstein Barr virus (EBV): Diagnostic procedures for viral, rickettsial, and chlamydial infections. Washington: American Public Health Association.

2. Cohen JI (2000) Epstein-Barr virus infection. N Engl J Med 343: 481-492.

3. Williams H, Crawford DH (2006) Epstein-Barr virus: the impact of scientific advances on clinical practice. Blood 107: 862-869.

4. Shah KM, Young LS (2009) Epstein-Barr virus and carcinogenesis: beyond Burkitt's lymphoma. Clin Microbiol Infect 15: 982-988.

5. Hess RD (2004) Routine Epstein-Barr virus diagnostics from the laboratory perspective: still challenging after 35 years. J Clin Microbiol 42: 3381-3387.

6. Matheson BA, Chisholm SM, Ho-Yen DO (1990) Assessment of rapid ELISA test for detection of Epstein-Barr virus infection. J Clin Pathol 43: 691-693.

7. Elgh F, Linderholm M (1996) Evaluation of six commercially available kits using purified heterophile antigen for the rapid diagnosis of infectious mononucleosis compared with Epstein-Barr virus-specific serology. Clin Diagn Virol 7: 17-21.

8. Luzuriaga K, Sullivan JL (2010) Infectious mononucleosis. N Engl J Med 362: 1993-2000.

9. Robertson P, Beynon S, Whybin R, Brennan C, Vollmer-Conna U, et al. (2003) Measurement of EBV-lgG anti-VCA avidity aids the early and reliable diagnosis of primary EBV infection. J Med Virol 70: 617-623.

10. Fafi-Kremer S, Morand P, Brion JP, Pavese P, Baccard M, et al. (2005) Longterm shedding of infectious Epstein-Barr virus after infectious mononucleosis. $\mathrm{J}$ Infect Dis 191: 985-989

11. Niesters HG, van Esser J, Fries E, Wolthers KC, Cornelissen J, et al. (2000) Development of a real-time quantitative assay for detection of Epstein-Barr virus. J Clin Microbiol 38: 712-715.

12. Ruiz G, Pena P, de Ory F, Echevarria JE (2005) Comparison of commercial Real-Time PCR Assays for Quantification of Epstein-Barr Virus DNA. J Clin Microbiol 43: 2053-2057.

13. Bauer CC, Aberle SW, Popow-Kraupp T, Kapitan M, Hofmann H, et al. (2005) Serum Epstein-Barr virus DNA load in primary Epstein-Barr virus infection. $J$ Med Virol 75: 54-58.

14. Berth M, Vanheule G, Depuydt C, Benoy I (2011) Serum Epstein-Barr virus (EBV) viral load can be a complementary sensitive test in primary Epstein-Barr virus infection. J Clin Virol 50: 184-185.

15. Berger C, Day P, Meier G, Zingg W, Bossart W, et al. (2001) Dynamics of Epstein-Barr virus DNA levels in serum during EBV-associated disease. J Med Virol 64: 505-512.

16. Yamamoto M, Kimura H, Hironaka T, Hirai K, Hasegawa S, et al. (1995) Detection and Quantification of Virus DNA in Plasma of Patients with EpsteinBarr Virus-Associated Diseases. J Clin Microbiol 33: 1765-1768.
17. She RC, Stevenson J, Phansalkar AR, Hillyard DR, Litwin CM, et al. (2007) Limitations of polymerase chain reaction testing for diagnosing acute EpsteinBarr virus infections. Diagn Microbiol Infect Dis 58: 333-335.

18. Pitetti RD, Laus S, Wadowsky RM (2003) Clinical evaluation of a quantitative real time polymerase chain reaction assay for diagnosis of primary EpsteinBarr virus infection in children. Pediatr Infect Dis J 22: 736-739.

19. Chan KH, Ng MH, Seto WH, Peiris JSM (2001) Epstein-Barr Virus (EBV) DNA in sera of patients with primary EBV infection. J Clin Microbiol 39: 4152-4154.

20. Kimura H, Morita M, Yabuta Y, Kuzushima K, Kato K, et al. (1999) Quantitative Analysis of Epstein-Barr Virus Load by Using a Real-Time PCR Assay. J Clin Microbiol 37: 132-136.

21. Luderer R, Kok M, Niesters HG, Schuurman R, de Weerdt O, et al. (2005) Real-time Epstein-Barr virus PCR for the diagnosis of primary EBV infections and EBV reactivation. Mol Diagn 9: 195-200.

22. Duan HM, Yao Y, Xie ZD, Yan J, Hu YH, et al. (2009) Determination of plasma EBV DNA in 91 children with EBV-associated diseases. Zhongguo Dang Dai Er Ke Za Zhi 11: 897-900.

23. Balfour HH Jr, Holman CJ, Hokanson KM, Lelonek MM, Giesbrecht JE, et al. (2005) A Prospective Clinical Study of Epstein-Barr Virus and Host Interactions during Acute Infectious Mononucleosis. J Infect Dis 192: 1505-1512.

24. Hoshino Y, Nishikawa K, Ito Y, Kuzushima K, Kimura H (2011) Kinetics of Epstein-Barr virus load and virus-specific CD8+ $T$ cells in acute infectious mononucleosis. J Clin Virol 50: 244-246.

25. Hadinoto V, Shapiro M, Greenough TC, Sullivan JL, Luzuriaga K, et al. (2008) On the dynamics of acute EBV infection and the pathogenesis of infectious mononucleosis. Blood 111: 1420-1427. 